\title{
Erratum
}

\section{Letter to the Editor - ERRATUM}

\section{Gill Thomson, Fiona Dykes, Andy Bilson, Jane Putsey, Mary Whitmore and Sally Dickens}

Doi: 10.1017/S1368980009992886, Published online by Cambridge University Press, 1 January 2010

The above article was published with an incorrect spelling of Fiona Dykes' first name; 'Fiona' was given as 'Fona'.

\section{Reference}

Thomson G, Dykes F, Bilson A, Putsey J, Whitmore M \& Dickens S (2010) Letter to the Editor. Public Health Nutrition 13(1), 149-50. doi: 10.1017/S1368980009992886 